\title{
NON-COMMON-SENSICAL: AN INFERENCE OF GUILT TO SANCTION NON-COMPLIANCE WITH DEFENCE DISCLOSURE
}

\author{
Jesse Slankard*
}

The Criminal Procedure (Reform and Modernisation) Bill is currently before the New Zealand Parliament. The Bill will implement mandatory defence disclosure of the issues in dispute at a pretrial hearing stage. This paper addresses the enforcement mechanism adopted by the Bill - an inference of guilt from non-compliance - and examines the suitability of the inference as an enforcement mechanism. It outlines the compatibility of the inference with the existing framework of evidence law in New Zealand and suggests changes to the Bill that are necessary to ensure the inference is exercised in a consistent and justifiable way.

\section{INTRODUCTION}

In New Zealand, defendants in criminal proceedings are presumed innocent until proven guilty. The burden of proving the defendant's guilt is on the prosecution and the standard of proof required is beyond a reasonable doubt. ${ }^{1}$ These procedural rights are guaranteed to defendants by the New Zealand Bill of Rights Act 1990 (BORA) and are fundamental to securing the just determination of criminal proceedings. ${ }^{2}$ As a case against a defendant can never be proved beyond all doubt, logical inferences from established facts are unavoidable in the fact-finding process. ${ }^{3}$

The Criminal Procedure (Reform and Modernisation) Bill (the Bill) is currently before the New Zealand Parliament. The Bill will implement mandatory defence disclosure of the issues in dispute at a pre-trial hearing stage (the issues identification process). This paper will analyse the

* This paper was submitted as part of the LLB(Hons) degree at Victoria University of Wellington. The author expresses his thanks to his supervisor Dr Yvette Tinsley.

1 New Zealand Bill of Rights Act 1990, s 25(c).

2 Evidence Act 2006, s 6(b).

3 Glanville Williams The Proof of Guilt (3rd ed, Steven \& Sons, London, 1963) at 190. 
enforcement mechanism adopted by the Bill - an inference of guilt from non-compliance - and examine the suitability of the inference as an enforcement mechanism.

First, it will outline the existing legal framework of evidence law in New Zealand. The author contends that an inference of guilt from non-compliance with the issues identification process is analogous to inferences from silence at other stages of the trial. Thus, the arguments and reasoning relating to the immunities afforded by the right to silence will contribute to determining the logical basis of the inference proposed by the Bill. In particular, it will focus on the argument justified by 'common sense' that silence in the face of accusations is evidence of guilt.

Second, similar developments in England and Wales will be used to analyse the efficacy of the inference of guilt as an enforcement mechanism. This analysis will explain the opposing purposes of the inference, sanctioning and fact-finding.

Finally, it will address the relevant clauses of the Bill and suggest factors that are necessary to ensure that only logical inferences, consistent with the defendant's procedural rights, are drawn from non-compliance with the issues identification process. By incorporating the suggested mandatory considerations in to the Bill and expressly limiting the extent of the inference to be drawn, this paper submits that the correct balance between both the sanctioning and fact-finding functions of the Bill will be struck. Consequently, the inference would be capable of being exercised in a consistent and just way.

\section{THE ISSUES IDENTIFICATION PROCESS}

\section{A The Identification of Issues in Dispute}

The object of the issues identification process is to introduce efficiency into New Zealand's criminal procedure which the Ministry of Justice (Ministry) perceives as "unnecessarily complex". 4 The Ministry believes that mandatory advanced disclosure of the issues in dispute by the defence will assist in remedying such complexity. Under the issues identification process the defendant would be required to give notice of any particular elements of the offence that he or she contends cannot be proved and any particular defence, justification, exception, exemption, proviso, or excuse which he or she intends to rely on. ${ }^{5}$ Conduct that fails to comply with these requirements includes; failing to give adequate notice of any of the above; giving notice that all issues are in dispute without indicating a particular issue; and giving notice of mutually contradictory defences. ${ }^{6} \mathrm{An}$ in depth analysis of the likely success of this process or its implications on the procedural rights of the

4 Ministry of Justice Discussion Document: Identification of the Issues in Dispute (Ministry of Justice, 2009) at [1].

5 Criminal Procedure (Reform and Modernisation) Bill R 4.2.1(d), cl 64.

6 Ibid, cl 34. 
defendant is outside the scope of this paper. Instead, this paper will focus on the method of ensuring compliance with the issues identification process.

The Ministry plan to ensure compliance with the issues identification process by allowing the fact-finder to draw an inference of guilt from a defendant's non-compliance. ${ }^{7}$ In the event of a failure by the defendant to identify the issues in dispute within the specified time before any trial, the sanction would confer a discretionary power on the prosecution or the judge to "invite the factfinder to draw any inference about the guilt of the defendant from that failure that appears proper in the circumstances". 8

\section{B The Repeal of s 32(1)(b) of the Evidence Act 2006}

The issues identification process expands existing requirements for prior disclosure of alibi or expert evidence under the Criminal Disclosure Act 2008. Section 22 requires the defendant to provide written notice to the prosecution, within a specified time, of the particulars of any alibi he or she intends to rely on. Section 23 imposes similar requirements with regard to prior disclosure of expert evidence. Section 34 provides that where these requirements are not met the court may order that the evidence be excluded. The distinction between the issues identification process and the disclosure requirements under the Criminal Disclosure Act is the intended method of enforcement. The sanction proposed by the Ministry is a significant departure from established principles of criminal procedure in New Zealand.

Section 32 of the Evidence Act 2006 provides that the fact-finder cannot be invited to infer guilt from a defendant's silence before trial. This includes a failure to answer questions under police interrogation, ${ }^{9}$ as well as a failure to disclose a defence before trial. ${ }^{10}$ Section 33 prevents the prosecution from commenting on the defendant's failure to give evidence at trial. Implementation of the issues identification process requires the repeal of s 32(1)(b) which protects the accused from adverse comment for a failure to disclose a defence before trial.

Sections 32 and 33 of the Evidence Act codify one aspect of the long established principle of common law known as the right to silence. In particular, these sections protect the immunity of persons being tried from being subject to adverse comment on their failure to answer questions before the trial or to give evidence at trial. ${ }^{11}$ The Ministry contend that s 32(1)(b) sits awkwardly

7 Ministry of Justice, above n 4, at [78].

8 Criminal Procedure (Reform and Modernisation) Bill R 4.2.1(d), cl 114

9 Evidence Act 2006, s 32(1)(a).

10 Ibid, s 32(1)(b).

11 Susan Easton The Case for the Right to Silence (2nd ed, Ashgate, Aldershot, 1998) at 3. 
amongst these provisions and is not an immunity consistent with the right to silence. ${ }^{12}$ However, this contention relies solely on the recognition of the right in the BORA, ignoring its extensive common law history.

In Smith v Director of Serious Fraud Office ${ }^{13}$ Lord Mustill described the right to silence as "a disparate group of immunities, which differ in nature, origin, incidence and importance, and also as to the extent to which they have been encroached upon by statute". ${ }^{14}$ The purpose of this bundle of rights is threefold: first, to ensure the reliability of confessions; second, to protect persons from the abuse of power by the state; and third, to recognise the right to privacy, autonomy and dignity. ${ }^{15}$ These purposes reflect the historical development of the right to silence in response to the abuses of the state against the individual, typified by the coercive procedures of the Star Chamber in the 16th and 17 th centuries. ${ }^{16}$

The Ministry asserts that the right to silence is limited to its particular recognition in the BORA. Section 23(4) allows for persons arrested or detained to refrain from making a statement. Section 25(d) allows for persons not to be compelled to be a witness or to confess guilt. The Ministry contends that these provisions do not constitute a right to literal and continuous silence. Instead, they are limited to: the right not to answer questions of law enforcement officers in the course of their investigations; and the right to elect not to give evidence at trial. ${ }^{17}$ Accordingly, the Ministry contends that the proposed advanced disclosure requirement and the repeal of s 32(1)(b) do not encroach on the right to silence.

However, the Ministry's narrow interpretation of the right is inconsistent with the description given by Lord Mustill and and with the origins of the right as a protection against state coercion. American jurist John Henry Wigmore put forward the argument that individuals are not required to respond to allegations made by the state as follows: "the individual is sovereign and proper rules of battle between government and the individual require that the individual not be conscripted by his opponent to defeat himself". ${ }^{18}$ Any requirement that the defendant disclose his or her argument by identifying issues in dispute before they may have intended to do so seems contrary to the

12 Ministry of Justice, above n 4, at [54]. See also Ministry of Justice Supplementary Legal Consultation Issue: Adverse Inference from Defendant's Failure to Give Evidence (Ministry of Justice, 2009) at [25].

13 Smith v Director of the Serious Fraud Office [1993] AC 1 (HL).

14 Ibid, at 31 .

15 Paul Rishworth The New Zealand Bill of Rights (Oxford University Press, Auckland, 2003) at 646.

16 Easton, above n 11, at 3. See also the description of the procedures of the Star Chamber given by Lord Mustill in Smith v Director of Serious Fraud Office, above n 13, at 32.

17 Ministry of Justice, above n 4, at [54].

18 J McNaughton Wigmore on Evidence (Little Brown, Boston, 1966) vol 8 at 318; cited in Rishworth above $\mathrm{n}$ 15 , at 647 . 
sovereignty of the individual and Wigmore's "rules of battle". Kevin Dawkins illustrates this point by referring to pre-trial disclosure as a game of cards, where defendants are unnaturally required to "show [their] hand" in advance. ${ }^{19}$ Such transparency is a recent phenomenon in criminal procedure. Indeed, before the introduction of the alibi and expert evidence exceptions, it was understood that the right to silence in the police station extended to the preparatory stages before the trial and to the trial itself. ${ }^{20}$ Steven Greer refers to advanced disclosure upon pain of adverse comment as "abolition of the right to remain silent between charge and trial". ${ }^{21}$

These arguments suggest that the compatibility of the issues identification process with the right to silence is contestable. This paper will not attempt to resolve this issue. Instead, the author contends that the inference of guilt from failure to disclose a defence pre-trial proposed by the Ministry is analogous to inferences drawn from silence at other stages of the trial. ${ }^{22}$ Therefore, the reasoning and arguments relating to these inferences provide a basis for assessing the justifiability of the inference proposed by the Ministry.

\section{THE DEFENDANT'S PROCEDURAL RIGHTS}

The repeal of s 32(1)(b) of the Evidence Act would permit the fact-finder to use a defendant's failure to disclose a defence pre-trial as evidence of guilt. The law of evidence in New Zealand is codified by the Evidence Act. Section 6 sets out the overarching principles in this area of the law. In accordance with subsections (a) and (b), the Evidence Act secures the just determination of criminal proceedings by ensuring the application of logical rules that recognise the importance of the defendant's rights affirmed by the BORA, including the presumption of innocence.

\section{A The Presumption of Innocence}

It is a fundamental principle of the common law that the prosecution prove its case beyond a reasonable doubt. The "golden thread" of the common law is that the burden of proof rests with the prosecution. In Woolmington $v$ DPP Viscount Sankey LC stated: ${ }^{23}$

19 Kevin Dawkins "Defence Disclosure and Criminal Cases" [2001] 1 NZLR 35 at 38.

20 Michael Zander Cases and Materials on the English Legal System (10th ed, Cambridge University Press, New York, 2007) at 302.

21 Steven Greer "The Right to Silence, Defence Disclosure and Confession Evidence" [1994] 21 Brit J Law \& Soc 102 at 102 .

22 There are differences of opinion on this analogy. See for example, Latham LJ's judgment in $R v$ Bryan (Antonio) [2004] EWCA Crim 3467 at [22]. However, this paper contends that the analogy is a useful way of assessing the relevant issues in determining whether an inference should be drawn and the compatibility of the inference with the defendant's procedural rights. This contention is endorsed by Mike Redmayne "Criminal Justice Act 2003: Disclosure and its Discontents" [2004] Crim LR 441; see also $R v$ Daha Essa [2009] EWCA Crim 43.

23 Woolmington $v$ DPP [1935] AC $462(\mathrm{HL})$ at 482. 
No matter what the charge or where the trial, the principle that the prosecution must prove the guilt of the prisoner is part of the criminal law of England and no attempt to whittle it down can be entertained.

Glanville Williams identifies the connection between the presumption of innocence and the burden of proof: "when it is said that a defendant to a criminal charge is presumed innocent, what is really meant is that the burden of proving his guilt is upon the prosecution". ${ }^{24}$ In New Zealand, the presumption of innocence is affirmed by s 25(c) of the BORA. In accordance with William's comment, the presumption is regarded as having three components. First, it allocates the burden of proving guilt to the prosecution. Second, it requires guilt to be proved beyond a reasonable doubt. Third, the matter to be proved is guilt. ${ }^{25}$

In $R v$ Wanhalla $^{26}$ the Court of Appeal provided a corroboration of the various authorities on the concept of reasonable doubt. ${ }^{27}$ The majority determined, given that it is virtually impossible to prove anything to an absolute certainty when dealing with the reconstruction of past events, that the prosecution need only prove its case beyond a reasonable doubt. A reasonable doubt is an honest and reasonable uncertainty about the guilt of the accused after careful and impartial consideration of all the evidence. ${ }^{28}$

However, the rule that the burden of proving the defendant's guilt beyond reasonable doubt rests with the prosecution, does not determine what evidence can be taken into account. ${ }^{29}$ It is because of this very difficulty in proving anything with absolute certainty that the occurrence of past events, which constitute most factual issues in court, remains a matter of inference rather than observation. ${ }^{30}$ It follows that the above guarantees do not immunise a person from inferences available to judges and juries as a matter of logic. ${ }^{31}$

\section{$B$ Inferences}

It is common practice for the prosecution to prove elements of an offence with reliance on inferences drawn from the evidence. ${ }^{32}$ In general, inferences may be drawn from proved facts if

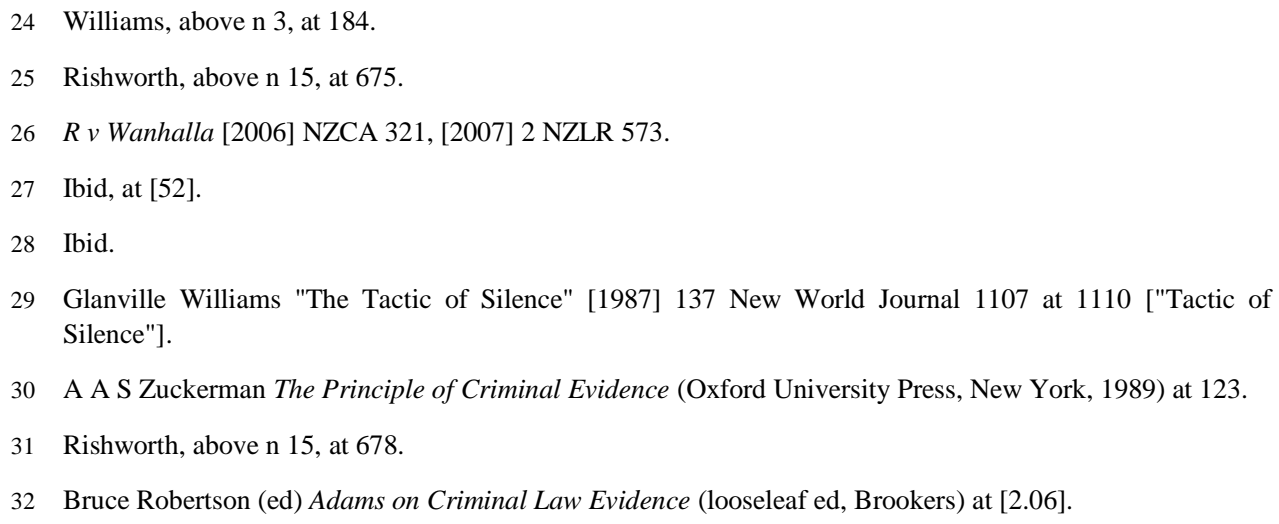


they follow logically from them. If they do not, then the drawing of any conclusion is no more than speculation and the requisite burden of proof will not be met. ${ }^{33} \mathrm{~A}$ common example of a logical inference is provided in $R v$ Priday: ${ }^{34}$

A man comes into the courtroom wearing a coat which is dripping wet. In his hand he carries an umbrella. From that, you could draw an inference that the man had just come into the building and that it

is raining or has just been raining outside.

Therefore, logical inferences are an ordinary part of the fact-finding process and are consistent with the procedural rights guaranteed at common law and under the BORA. Conversely, an illogical inference is contrary to the defendant's procedural rights under the BORA and therefore jeopardises the just determination of criminal proceedings. The next part of the paper will address the argument from common sense that it is logical to infer guilt from silence.

\section{THE ARGUMENT FROM COMMON SENSE}

As Lord Mustill suggested, the immunities afforded by the right to silence are not absolute. In New Zealand and overseas, courts have held that it is not inconsistent with the right for a fact-finder to draw a logical inference from a defendant's failure to give evidence in circumstances where he or she would be expected to do so. ${ }^{35}$ Drawing such an inference, it is commonly asserted, merely aligns the fact finders reasoning with common sense.

\section{A The Weapon of the Guilty}

The argument from common sense conceives of the right to silence as a "weapon of the guilty", ${ }^{36}$ and can be traced back to the jurisprudence of Jeremy Bentham. Bentham's claim, that if all the criminals of every class met and framed a system after their own wishes the right to silence is the first rule they would establish, ${ }^{37}$ reflects his concern that the right is of no use to the innocent. The only interest of the innocent is to "dissipate the cloud which surrounds their conduct by giving an explanation for it". ${ }^{38}$ It follows that preventing adverse comment from silence is counter intuitive as common sense would equate such silence with guilt. ${ }^{39}$

33 Ibid.

$34 \quad R v$ Priday [2002] NZCA 156 at [11].

35 Rishworth, above n 15, at 646. See also Ministry of Justice, above n 12, at [7]; Trompert v Police [1985] 1 NZLR 357; and Criminal Justice and Public Order Act 1994.

36 Easton, above n 11, at 133

37 M Durmont and Ettienne Durmont A Treatise on Judicial Evidence: Extracted from the Manuscripts of Jeremy Bentham (William S Hein \& Co, London, 1825) at 241.

38 Ibid.

39 Easton, above n 11, at 154 
In England and Wales in 1972, the Criminal Law Revision Committee (CLRC) published a report on the right to silence quoting with approval Bentham's remark that "innocence claims the right of speaking, as guilt invokes the privilege of silence". ${ }^{40}$ Despite subsequent reports from judicial bodies expressing contrary opinions, ${ }^{41}$ the Eleventh Report on Criminal Evidence from the CLRC was eventually adopted, forming the basis for extensive reforms in England and Wales. In New Zealand, these common sense assumptions of the CLRC's report form the basis of the Trompert principle.

\section{$B$ The Trompert Principle}

Section 33 of the Evidence Act expressly forbids only the prosecution from commenting on a defendant's silence, leaving such comment open for the judge or the defendant. In Trompert $v$ Police, the Court of Appeal held that once the prosecution establishes a prima facie case, the court is entitled to take into account the accused's failure to give or call evidence, if such evidence could provide the explanation that the defendant might be expected to give if he or she were innocent. ${ }^{42}$ Cooke $\mathrm{P}$ gives a summary of the New Zealand position in $R v$ Butcher: ${ }^{43}$

The law certainly allows an inference adverse to an accused to be drawn if he remains silent at trial in the face of evidence pointing to his guilt... the accused is not bound to give evidence, but he refrains at the foregoing risk, so the expression right to silence can be somewhat misleading. Where the expression is more appropriate is in relation to matters outside the trial. It is elementary that in general a suspect has a right to silence under interrogation from the police or other law enforcement officers, whether before or after caution.

Therefore, the Trompert principle is an exception to the immunity of defendants from being subjected to adverse comment from their failure to give evidence at trial. Under the current law, the ability to comment is limited to silence at trial and does not extend to any other stage.

40 Criminal Law Revision Committee Eleventh Report on Evidence (Criminal Law Revision Committee, 1972) cited in Home Office Report of the Working Group on the Right to Silence (Home Office, London, 1989) at [21].

41 See, for example Royal Commission on Criminal Procedure Phillips Report (1981).

42 Trompert v Police, above n 35, at 358. See also Purdie v Maxwell [1960] NZLR 599.

$43 \quad R v$ Butcher [1992] 2 NZLR 257 at 268. See also Drain $v$ Police [1994] 11 CRNZ 576; $R v$ Hines [1998] 16 CRNZ 236; and $R$ v Clarke CA417/93, 16 December 1993. 


\section{The England and Wales Reforms}

This is not the case in England and Wales which, in the 1990s, went through what has been labelled "one of the most controversial reforms of the 20th century". ${ }^{44}$ In July 1987 the Home Office Secretary made the following comments: ${ }^{45}$

Is it really in the interests of justice, for example, that experienced criminals should be able to refuse to answer all police questions secure in the knowledge that a jury will never hear of it? Does the present law really protect the innocent whose interests will generally lie in answering questions frankly? Is it really unthinkable that the jury should be allowed to know about the defendant's silence and, in the light of the other facts brought to light during a trial, be able to draw its own conclusions?

In accordance with this argument, criminal procedure in England and Wales was reformed and the immunities afforded by the right to silence were considerably reduced. In 1994, the Criminal Justice and Public Order Act (CJPOA) was passed allowing for adverse comment from a defendant's silence in a variety of circumstances including failure to respond to police questioning pre-trial. ${ }^{46}$ The CJPOA was followed by the Criminal Procedure and Investigations Act 1996 (CPIA) which implemented a mandatory disclosure regime by the defendant of the issues in dispute. ${ }^{47}$ Upon a defendant's failure to comply, $\mathrm{s} 11$ of the CPIA provides that the judge or the prosecution may make "such comment as appears appropriate", ${ }^{48}$ and "the court or jury may draw such inferences as appear proper in deciding whether the accused is guilty".49

\section{A Consciousness of Guilt}

In New Zealand, the Bill would confer a broad discretion on the judge and the prosecution to comment on the defendant's non-compliance with the issues identification process. The fact-finder may be invited to draw any inference about the guilt of the defendant that "appears proper in the circumstances". ${ }^{50}$ This process would allow an inference of guilt to be drawn where the defendant: fails to disclose a defence later relied on at trial; gives notice of mutually contradictory defences; or gives notice that everything is in dispute. ${ }^{51}$ The logic of this inference is that these examples of non-

44 A Jennings, A Ashworth and B Emmerson "Silence and Safety: The Impact of Human Rights Law" [2000] Crim LR 879 at 879.

45 Home Office, above n 40, at [1].

46 Criminal Justice and Public Order Act 1994 (E\&W), s 34.

47 Criminal Procedure and Investigations Act 1996 (E\&W), s 5.

48 Ibid, s 11(3)(a).

49 Ibid, s 11(3)(b); see also Michael Zander, above n 20.

50 Criminal Procedure (Reform and Modernisation) Bill, cl 114

51 Ibid, cl 67. 
compliance establish a consciousness of guilt. This logic is easily illustrated by assessing the analogous operation of s 34 of the England and Wales CJPOA. ${ }^{52}$

In general, silence in the face of allegations may be used to infer a "consciousness of guilt". ${ }^{53}$ In New Zealand, under the Trompert principle, such inferences are confined to silence at trial when the evidence clearly calls for an explanation from the defendant which is not given. However, in England and Wales, s 34 of the CJPOA has extended this principle so that where a defendant relies on a fact at trial which he or she did not mention under police interrogation the fact-finder may draw an inference that the failure establishes a consciousness of guilt. In this situation an inference is drawn, from the belated introduction of the defence, of a consciousness at the time of the accusation that the defence did not exist. ${ }^{54}$ Therefore, the failure to mention the defence at the appropriate time undermines the credibility of the defendant and warrants the adverse inference. ${ }^{55}$

The operation of s 34 is illustrated in $R v$ Argent. ${ }^{56}$ The defendant was arrested after the police received a tip off that he had been involved in the killing of a man outside of an English tavern. The defendant remained silent throughout police questioning but at trial provided an innocent account of his conduct on the night of the killing. The trial judge employed s 34 and instructed the jury as follows: 57

If you are sure that the defendant did fail to mention those facts and that in all the circumstances existing at the time he could reasonably have been expected to mention them, you are entitled to draw such inferences from this failure as you think proper. In judging this matter ... you apply your ordinary common sense ... you are entitled to consider whether the reason for the failure was because the defendant had not thought out all the facts ... or that he had no innocent explanation to offer or none which he believed would then stand up to scrutiny and that may cast doubt upon the truthfulness of his account now.

On appeal, the trial judge's direction was applauded as a model of comprehensiveness. ${ }^{58}$ It was affirmed that any inference under s 34 is for the fact-finder to decide using "common sense, experience and understanding of human nature". 59

52 Redmayne, above $\mathrm{n} 22$, at 446.

53 J D Heydon "Silence as Evidence" [1974] 1 Monash U L Rev 53 at 54.

54 Ibid.

55 Although the term "credibility" has been replaced in the law of evidence by the terms "propensity" and "veracity", it is useful in this context to encapsulate the logic of the inference.

$56 \quad R v$ Argent [1997] 2 Cr App R 27.

57 Ibid; Susan Easton "Legal Advice, Common Sense and the Right to Silence" (1998) 2 E\&P 109 at 114 ["Legal Advice"].

58 Easton, ibid. 
The judicial direction in Argent suggests that a consciousness of guilt under s 34 of the CJPOA will only be attributed to a defendant for failing to mention facts that he or she could reasonably have been expected to mention under interrogation. ${ }^{60}$ Similarly, a logical inference against a defendant who fails to disclose a defence pre-trial should also depend on what he or she could reasonably have been expected to disclose.

\section{E Opposition to Common Sense}

Despite Glanville Williams' belief that silence will indicate guilt in almost all circumstances, ${ }^{61}$ the argument from common sense has not been unanimously embraced. In fact, it has been met with considerable academic criticism. Susan Easton contends that the argument from common sense is a poor model for the law to follow, given that it is "untested, speculative, highly contentious, unreliable, impressionable and unsystematic". ${ }^{2}$ Michael Salter defines common sense as: ${ }^{63}$

$[\mathrm{N}]$ either an overt consensus or public opinion, nor a particular instance of folk wisdom. Instead, it takes the form of a self justifying mode of interpreting capable of being applied to any particular topic: one which forecloses on the possibilities of sustained theoretical inquiries including not the least those into the structure and operation of common sense itself.

Salter emphasises the danger in common sense reasoning which, due to its intuitive belief system, has the potential to act as a barrier to an examination of the very premises on which claims of common sense are made. ${ }^{64}$ Salter's critique of common sense reasoning is consistent with Easton's concern that a blanket inference of guilt from silence will lead to injustices. For Easton, the argument is dangerous precisely because it may equate silence with guilt. She points out that there may be a number of reasons for remaining silent in the face of accusations which are not indicative of guilt. ${ }^{65}$ The problem identified by Easton is how to distinguish between suspicious and innocent silence. ${ }^{66}$

As discussed above, inferences are an unavoidable part of the fact-finding process and such inferences inevitably rely on the employment of common sense. The competing theories as to the

59 Ibid.

60 Roger Leng "Silence Pre-Trial: Reasonable Expectations and the Normative Distortion of Fact-Finding" (2001) 5 E\&P 240.

61 Williams "The Tactic of Silence", above n 31, at 1107.

62 Easton, above n 11, at 155

63 M Salter "Common Sense and the Resistance to Legal Theory" (1992) 5 Ratio Juris 212 at 212.

64 Ibid; P J Shwikkard "Silence and Common Sense" (2003) Acta Juridicia 92 at 96.

65 Easton, above n 11, at 155.

66 Ibid. 
correct application of common sense with regards to inferences drawn from silence can be reconciled by considering its necessarily circumstantial application. PJ Shwikkard points out that common sense is invariably influenced by available knowledge. ${ }^{67}$ Shwikkard's analysis is reinforced by the conservative approaches taken when drawing inferences from silence. In New Zealand, the Trompert principle is rarely applied and judges often do not comment when an accused has failed to give evidence. ${ }^{68}$ Similarly, the England and Wales reforms have been characterised by ineffectiveness and in certain circumstances are considered unenforceable. ${ }^{69}$ Such hesitation indicates a weak correlation between mere silence and guilt. Further, as Charles Nesson states, "if the contexts which engender legislative directions of permissive inferences are typified by weak circumstantial proof then courts evaluating the legislative direction will often find themselves pushed to the limit to justify the inference".${ }^{70}$ In other words, if the inference permitted under the Bill is required to be drawn largely in situations where the other evidence of guilt is slim then courts will be hesitant to use it. It follows that in order to draw a logical inference from a failure to identify issues in dispute it is necessary to consider whether in the context of the failure actually indicates guilt. The contextual nature of, and hesitation surrounding the application of the inference, is problematic as it undermines one of the purposes of the inference under the issues identification process - to sanction non-compliance.

\section{F Sanctioning and Fact-Finding}

The issues identification process is inspired by the England and Wales reforms, in particular the CPIA, and its preferred method of enforcement is consistent with s 11 of that Act. In light of the problems experienced in England and Wales with regards to the effective functioning of the CPIA, this is a curious model to follow. The England and Wales reforms have been characterised by "chronic ineffectiveness" 71 and it is clear that the regime is not functioning as intended. ${ }^{72}$ Indeed, in 2005, New Zealand's own Law Commission (the Commission) issued a critique of the England and Wales. ${ }^{73}$ The Commission expressly dismissed drawing an inference of guilt from a failure to identify issues in dispute, which it described as "self evidently problematic". ${ }^{74}$ The Commission's

67 Shwikkard, above n 64, at 96.

69 Redmayne, above n 22, at 447.

70 Charles R Nesson "Reasonable Doubt and Permissive Inferences: the value of complexity" (1979) 92 HLR 1187 at 1189

71 David Ormerod "Improving the Disclosure Regime" (2003) 7 E\&P 102 at 102.

72 See the reforms made by the Criminal Justice Act 2003. See also Zander, above n 20

73 Law Commission Criminal Pre-Trial Processes: Justice through Efficiency (NZLC R8, 2005).

74 Ibid, at [201]; further comments from the Commission are included below. However, the Commission provided no express reasons for this conclusion. 
opposition to the England and Wales reforms is consistent with the proposition that the inference is inherently flawed due to its dual purpose of both sanctioning and fact-finding. ${ }^{75}$

Inferences are common place in the process of fact-finding and inevitably used to assist the prosecution in proving the defendant's guilt beyond a reasonable doubt. In contrast, the proposed use of the inference as a sanction is intended to encourage parties to support and cooperate with the issues identification process. In instances where compliance does not occur, the inference is meant to operate to hold the defendant accountable and provide a deterrent against future acts of noncompliance. ${ }^{76}$ The amalgamation of both sanctioning and fact-finding is problematic in two respects. First, the fact-finding process has the potential to become distorted by inferences being imposed on the court for the purpose of sanctioning non-compliance without any logical connection to the guilt of the defendant. ${ }^{77}$ The second is a corollary of the first, if those inferences are not drawn because of the contextual ambiguities discussed above, the sanction will be ineffective and the issues identification process will not be enforced.

This tension is illustrated by the England Wales reforms and the implementation of the Criminal Justice Act 2003 (CJA). The CJA responded to the ineffectiveness of the CPIA by simplifying the ability to draw inferences from non-compliance. Further, it "sharpened the teeth"78 of the CPIA, removing the requirement that the prosecution obtain leave of the court before commenting on noncompliance and inviting an inference of guilt. ${ }^{79}$ Since the adoption of the CJA, the England and Wales courts have shown an increasing willingness to utilise the inference where the defendant has failed to satisfy their disclosure obligations. ${ }^{80}$

Despite its apparent success, the CJA does not resolve the tension between the sanctioning and fact-finding functions of the inference. Instead, by providing an indiscriminate inference of guilt, the CJA has favoured an effective sanction at the expense of the fact-finding process. Thus, the CJA ignores the context of non-compliance and undermines the just determination of criminal trials by permitting illogical inferences, inconsistent with a consciousness of guilt, to be drawn for the purpose of sanctioning.

In order for the inference to be consistent with the principles of evidence law in New Zealand, a balance must be struck between an effective sanction and an inference that does not distort the fact-

75 Leng, above n 60, at 242.

76 Ministry of Justice Discussion Document: Mechanisms to Ensure Compliance (Ministry of Justice, 2009) at [2].

77 Ibid.

78 Redmayne, above n 22, at 446.

79 Criminal Justice Act 2003 (E\&W), s 39.

80 Chris Taylor "Evolution of the Defence Statement" [2010] 3 JCL 214 at 212. 
finding process. ${ }^{81}$ The author contends that the only way to resolve this tension is by ensuring that the inference of guilt is applied in a consistent and justifiable way. The next part of the paper will analyse the Bill that will implement the issues identification process in New Zealand and suggest the changes necessary to achieve this end.

\section{THE BILL}

The Bill sets up the inference in two stages. First, cls 106, 112 and 113 determine when an inference of guilt can be employed. These clauses provide that before the prosecution or judge can comment on non-compliance with the issues identification process in a judge alone or jury trial, the judge must be satisfied that the defendant failed to adequately notify the issues in dispute, and no reasonable explanation can be given for that failure. Second, cl 114 limits the inference to be drawn from such non-compliance. ${ }^{82}$ Under this clause, while the judge or jury may draw "any inference from that failure that appears proper in the circumstances", they are not entitled to find the defendant guilty of an offence "solely" on the inference.

By restricting the prosecution to commenting only with leave of the court, the Bill provides flexibility, giving the court an opportunity to consider whether the context of non-disclosure justifies the inference. However, this process aligns the Bill with the ineffective England and Wales CPIA, suggesting that judges will be hesitant to utilise the inference. Such hesitation could be mitigated by providing a process whereby the discretion of the judge is guided by mandatory considerations and the evidential value of the inference is restricted.

\section{A Mandatory Considerations}

In order to ensure that where the court gives the prosecution leave to comment the circumstances of non-compliance justify an inference of guilt, the following mandatory considerations should be incorporated into the Bill: the persuasiveness of the prosecution's disclosure; the significance of the defendant's non compliance; and the defendant's understanding of the issues. These requirements will be considered in turn.

\section{Persuasive prosecution disclosure}

Under the current law, failure by the defence to disclose its case before trial is not immediately suspicious. The defence is under no obligation to disclose its case before the trial and early disclosure is not routinely done by most defence counsel. ${ }^{83}$ However, by creating a duty to disclose, the issues identification process attempts to change this perception and practice. In order to align the

81 See discussion under Part III.

82 See Criminal Procedure (Reform and Modernisation) Bill, cl 106 which sets up the same rules for judge alone trials.

83 Evidence Act 2006, s 32(1)(b). 
logic of drawing an inference from a failure to disclose a defence at pre-trial hearings with inferences drawn from silence at other stages of the trial, the circumstances must "clearly call for an explanation". ${ }^{84}$ The significance of this requirement is illustrated by the decisions of the European Court of Human Rights (ECHR) which validated the England and Wales reforms.

(a) The ECHR Decisions

In Murray $v$ United Kingdom ${ }^{85}$ the appellant, a member of the IRA, was found at a house with a police informant who was being held captive. He was charged with aiding and abetting false imprisonment and remained silent throughout police questioning and at trial. However, at trial his counsel argued that he had arrived at the house shortly before the police and his presence there was innocent and unrelated to the charge. The trial judge drew very strong inferences from the appellant's silence and these inferences were integral to the guilty verdict. ${ }^{86}$

The Court was asked to decide on the validity of the inferences that were drawn from the appellant's silence during police questioning and at trial. ${ }^{87}$ On this point, the Court considered that the question in each case is whether the evidence adduced by the prosecution is sufficiently strong to call for an answer: ${ }^{88}$

It is self evident that it is incompatible with the immunities under consideration to base a conviction solely or mainly on the accused's silence or on a refusal to answer questions or give evidence himself. However, it is equally obvious that these immunities cannot and should not prevent that the accused's silence, in situations which clearly call for an explanation from him, be taken into account in assessing the persuasiveness of the evidence against him.

The majority went on to conclude that the evidence adduced against the appellant called for an explanation which was not given. It followed, that as a matter of common sense there was no explanation and that the appellant was guilty: ${ }^{89}$

84 Averill v United Kingdom [2001] 31 EHRR 36 (ECHR); see also Di Birch "Suffering in Silence: A Cost Benefit Analysis of Section 34 of the Criminal Justice and Public Order Act 1994" (1999) Crim LR 767 at 777

85 Murray v United Kingdom [1996] 22 EHRR 29 (ECHR).

86 Ibid, at [24].

87 Inferences were drawn under the Criminal Evidence (Northern Ireland) Order 1988 and the issue was whether these were consistent with the European Convention on Human Rights, art 6. Although the judgment concerned the Northern Ireland Order, it was equally relevant to the similar England and Wales legislation which is within the jurisdiction of the ECHR. See Roderick Munday "Inferences from Silence and European Human Rights Law" [1996] Crim LR 370 at 385.

88 Murray v United Kingdom, above n 85, at [47].

89 Ibid, at [54]. 
Having regard to the weight of the evidence against the applicant, the drawing of inferences from his refusal at arrest, during police questioning and at trial, to provide an explanation for his presence in the house was a matter of common sense and cannot be regarded as unfair or unreasonable.

Material to the majority's decision in Murray was the extent of the case against the appellant. The majority stressed that a conviction may not be based "solely or mainly" on silence. However, it is unclear from Murray when evidence will "clearly call for an explanation" which must inevitably be a matter of fact and degree. ${ }^{90}$ Roderick Munday expressed a cautious response to the ruling in Murray, describing the outcome as only a "qualified approval" of the England and Wales reforms. ${ }^{91}$ Munday reasoned that "due to the formidable case the likelihood that the Court would have considered it unreasonable to draw additional inferences from Murray's silence in this case was slim." 92 Despite the apparent uncertainty in the wake of Murray, the Court reaffirmed its decision in Averill $v$ United Kingdom. ${ }^{93}$ Again, in Averill the case against the appellant was significant. ${ }^{94}$

For present purposes, these decisions are problematic as they do not appear to distinguish between maintaining silence pre-trial and maintaining silence in the face of the court. ${ }^{95}$ Thus, the decisions fail to take into account that the accused cannot reasonably be expected to mention a defence unless he has knowledge of the evidence against him. ${ }^{96}$ It remains to be considered then, how the reasoning from Murray can be reconciled with non-compliance under the Bill.

(b) Prosecution Disclosure

In a 1993 England and Wales study it was concluded that in almost half of the cases where silence was invoked under police interrogation it was due to a lack of knowledge of the police case. ${ }^{97}$ A solicitor explains this figure: "In that situation... where you don't know what the case is against you, generally speaking, the best advice that we can give in our clients' interests is to say 'no

90 Munday, above n 87, at 377.

91 Ibid, at 385 .

92 Ibid, at 371.

93 Averill v United Kingdom, above n 84.

94 Ibid, at [23]; The appellant was linked to a crime scene by forensic evidence which "strongly supported" his presence there.

95 Munday, above $\mathrm{n} 87$, at 375.

96 I Dennis "The Criminal Justice and Public Order Act: The Evidence Provisions" [1995] Crim LR 4 at 16.

97 Mike McConville and Jacqueline Hodgson Custodial Legal Advice and the Right to Silence (Royal Commission on Criminal Justice Research Study, 1993) at 90; see also Di Birch "Suffering in Silence: A Cost Benefit Analysis of Section 34 of the Criminal Justice and Public Order Act 1994" (1999) Crim LR 767 at 777 
comment"'. ${ }^{98}$ It follows, that "meaningful" prosecution disclosure at the pre-trial hearing stage is essential to ensuring compliance from the defence. ${ }^{99}$ Under s 13(2) of the Criminal Disclosure Act 2008 , the prosecution is required to disclose "any relevant information" 100 to the defendant as soon as is reasonably practicable. ${ }^{101}$ However, in accordance with s 16 , the prosecution may withhold information from the defence in a long list of non-exhaustive circumstances. ${ }^{102}$ Thus, there is a high potential for insufficient prosecution disclosure. Roger Leng refers to insufficient prosecution disclosure as "the information deficit", ${ }^{103}$ and illustrates how deficiencies in prosecution disclosure could prejudice the defendant. He states that "it is not fanciful to imagine a defendant who is genuinely ignorant of the relevant events and therefore unable to formulate a defence statement". ${ }^{104}$ Therefore, at the pre-trial stage the prosecution must meet its disclosure requirements under the Criminal Disclosure Act. Furthermore, by applying the reasoning from the ECHR decisions, one could add that the disclosed case must be strong enough to clearly call for an explanation from the defendant before an inference is drawn. It is unclear from the ECHR the extent of the evidence required in this regard, which must inevitably be a matter of fact and degree. However, given the extent of the evidence against the appellants in both Murray and Averill, one could conclude that these cases set a rather high watermark. ${ }^{105}$

The above reasoning highlights the significance of prosecution disclosure. If non-compliance at the pre-trial hearing stage is to attract an inference of guilt, meaningful prosecution disclosure is necessary to establish circumstances which clearly call for an explanation. If prosecution disclosure is insufficient, the potential prejudice to an ill-informed defendant is twofold. First, the defendant may fail to meet the disclosure requirements, subjecting him or her to an inference of guilt. Second, if the defendant were to acquire previously undisclosed information at trial which called for the introduction of a new defence, the defendant would be unable to do so without suffering a similar fate. Such injustice could be avoided if the court is required to address the adequacy of prosecution disclosure before any comment is made.

98 Mike McConville and Jacqueline Hodgson, above n 97, at 90.

99 Kevin Kerrigan "Right to a Fair Trial" [1999] 4 J Civ Lib 280 at 292.

100 Criminal Disclosure Act 2008, s 13(3).

101 Ibid, s 13(1).

102 Ibid, s 13; see subss (a)-(o)

103 Roger Leng "Defence Strategies for Information Deficit Negotiating the CPIA" [1997] 1 E\&P 215 at 217 ["Strategies for Information Deficit"].

104 Ibid, at 218. See also $R v$ Tucker [2008] EWCA Crim 3063 and Swash v Director of Public Prosecutions [2009] EWHC 803.

105 Munday, above n 87, at 385. 


\section{Significant non-compliance}

Having established that persuasive prosecution disclosure is necessary to create circumstances which clearly call for an explanation from the defendant, it is necessary to address the extent of defence disclosure required by the Bill. Clause 64 of the Bill determines what must be disclosed by the defendant, demanding the disclosure of any particular defence, justification, exception, exemption, proviso, or excuse which it intends to rely on at trial. Clause 67 states that the defendant must not: identify mutually exclusive defences; identify that all issues are in dispute; fail to adequately notify the issues in dispute. The issue not dealt with by these clauses is how to distinguish between minor procedural non-compliance and failures that do undermine credibility.

Comment on mutually contradictory defences is relatively straightforward and should pose few problems. The Ministry provides the following example: a defendant charged with a sexual offence would disclose mutually exclusive defences by claiming that he or she was not the offender and that he or she had a reasonable belief in the complainant's consent. ${ }^{106}$ In this case, if both defences were argued at trial, the truth of each claim would rely on the falsehood of the other. Accordingly, such non-compliance undermines the credibility of each defence disclosed. A similar conclusion must be drawn where the defendant identifies that everything is in dispute. ${ }^{107}$ However, difficulties arise when considering the third instance of non-compliance, where the defendant is alleged to have failed to disclose a defence later relied on at trial.

The England and Wales experience shows that many defence statements fail to comply with the requirements under the CPIA. ${ }^{108}$ Often, defence statements are too general, doing little to achieve the purposes of the CPIA. ${ }^{109}$ The reason for general statements is clear - the more specific the defence statement the greater the potential for an adverse inference should the defence ultimately advanced at trial differ from what was disclosed. ${ }^{110}$ In $R v$ Tibbs, ${ }^{111}$ Beldam LJ attempted to resolve this issue by holding that a defence statement couched in the most general terms would frustrate the purpose of the disclosure provisions which was to facilitate a full identification and examination of any relevant material. ${ }^{112}$ Similarly, cl 67 of the Bill permits an inference where the defendant fails

106 Ministry of Justice Mechanisms to Ensure Compliance, above n 76, at [13].

107 To disclose that everything is in dispute will frustrate the purpose of the issues identification process and inevitably involve the disclosure of mutually contradictory defences.

108 Robin Ernest Auld Review of the Criminal Courts of England and Wales (Ministry of Justice 2001) at [158].

109 Ibid.

110 Taylor, above $\mathrm{n} 80$, at 218 .

$111 R v$ Tibbs [2000] 2 Cr App R 309.

112 Ibid, at [27]; Taylor, above n 80, at 218. See also the reforms made by the Criminal Justice Act 2003, s $33(2)$. 
to "adequately identify" issues in dispute. This raises a significant issue as to the degree of specificity required from defence disclosure and the extent of the discrepancy needed to warrant an inference of guilt. ${ }^{113}$

In Tibbs, the defendant was arrested after being caught exchanging three black rubbish bags full of cannabis for a large amount of cash. Under the requirements of the CPIA, the defendant denied the case against him claiming that he thought the bags contained tobacco and that he had been set up. He disclosed that he was delivering the bags for an accomplice and was to be paid $£ 100$ for this service. At trial, the figure was changed to $£ 150$ and the Judge allowed the prosecution to comment under s 11(3)(d) of the CPIA. ${ }^{114}$ The issue on appeal was whether the difference between $£ 100$ and $£ 150$ was significant enough to warrant an inference.

Beldam LJ held that it was. ${ }^{115}$ In so holding, the Lord Justice stressed the importance of $\mathrm{s}$ 11(4)(a) of the CPIA: ${ }^{116}$

The interests of the accused are safeguarded by this subsection, which leaves the judge with the discretion to decide whether the difference in the defence put forward is sufficiently significant to justify comment and the drawing of the inference.

In $R v$ Bryan, ${ }^{117}$ Latham $\mathrm{LJ}$ contended that before drawing any inference under the CPIA, the judge is obliged to consider the mindset of the defendant. ${ }^{118}$ The focus here must be whether the difference affects the credibility of the defendant. In cases such as Tibbs where the difference is a matter of degree, it will be more difficult to determine the mindset of the defendant from the failure. Thus, the significance of the non-compliance is essential to considering whether the credibility of the accused has been affected.

\section{The defendant's understanding of the issues}

If the judge concludes that the non-compliance does affect the credibility of the defendant, it must then be ascertained whether the fault lies with the defendant or defence counsel. The difficulty here is that the disclosure requirements proposed by the Bill go considerably beyond the obvious

113 Taylor, above $\mathrm{n} 80$, at 218 .

$114 R v$ Tibbs, above $\mathrm{n} 111$, at [15]. The comment was expressed as follows: "you are entitled to think it right that these changes indicate that Mr Tibbs was making up an improved story."

115 Ibid, at [30]. On appeal the issue was whether allowing the comment in those circumstances was "plainly wrong". Beldam LJ held that it was not, reasoning that the difference in price was capable of being a significant difference on a matter of importance.

$116 R v$ Tibbs, above n 111, at [29].

$117 R$ v Bryan (Antonio) [2004] EWCA Crim 3467

118 Ibid, at [26]. 
primary facts that a person can be expected to know. ${ }^{119}$ It is apparent from the England and Wales experience that the discharge of these duties requires assistance from defence counsel.

In its 2005 objection to the issues identification process, the Commission expressed the concern that the defendant could suffer due to an error of his legal counsel. ${ }^{120}$ The stance taken by the Commission reflects the difficulties experienced in England and Wales regarding the application of the inference. In a report delivered by Auld LJ, the Lord Justice criticised the ineffective operation of the CPIA, identifying the concern raised above: "[i]t would often be difficult to determine whether it was the defendant's or his lawyer's failure to comply." ${ }^{121}$ The Lord Justice went further, commenting that "assessing the materiality of issues or likely issues to the criminal trial is a lawyer's task." 122

The solution proposed by the England and Wales CJA was to provide that all defence statements are deemed to be given by the authority of the defendant. ${ }^{123}$ This is problematic as it avoids the substance of the issue - that the disclosure requirements go considerably beyond the obvious primary facts which a person can be expected to know. The Commission summarises this concern: "what the defendant is deemed to have said or done says nothing about his or her moral, as opposed to legal, responsibility for it and it says even less about the likelihood of his or her guilt in respect of the offence charged". ${ }^{124}$ As it is the credibility of the defendant in question, the court must ascertain whether the defendant had an understanding of the issues and therefore can be held responsible for the non-compliance.

\section{$B$ The Extent of the Inference}

Clause 114 confers a broad discretion on the judge or jury, allowing for "any inference that appears proper", however they are not entitled to find the defendant guilty "solely" on the inference. Such a broad direction is likely to produce inconsistencies and unset the balance between the sanctioning and fact-finding functions.

119 Leng "Defence Strategies for Information Deficit", above n 109, at 217. This point further distinguishes the inference from silence under interrogation. This distinction is important as legal advice under s 34 of the CJPOA does not prevent an inference being drawn, this is because the accused is capable of providing an answer regardless of whether he has been advised not to. See Easton "Legal Advice", above n 57, at 114; see also Condron v United Kingdom [2001] 31 EHHR 1. Conversely, due to the complexity of the disclosure regime the defendant, in most cases, will be wholly reliant on legal advice.

120 Law Commission, above n 73, at [201].

121 Auld, above n 108, at [181].

122 Ibid, at [176]. While this quote is taken from a comment on prosecution disclosure, it is equally applicable to defence disclosure which requires the same considerations in accordance with the Bill.

123 Criminal Justice Act 2003, s 36(1).

124 Law Commission, above n 73, at [201]. 
The evidential value that could be given to non-compliance under cl 114 may be broken down into two categories. ${ }^{125}$ First, non-compliance could be used to corroborate other evidence against the defendant. For present purposes this will be labelled a "general" inference of guilt. Second, it could be used to discredit a particular defence argued at trial. ${ }^{126}$ The author contends that this "particular" inference should be expressly and exclusively provided for by the Bill. The distinction between the two is that the general inference may be used to strengthen the prosecution's case, while the particular inference may only be used to weaken the case of the defence. ${ }^{127}$

\section{The general inference}

The problem with the general inference is its potential incompatibility with the requirement established by the ECHR decisions, that before an inference from silence can be drawn a prima facie case against the accused must be established. ${ }^{128}$

Di Birch comments that "it may happen that an otherwise weak prosecution case is fortified by reference to silence, and here there is a very strong danger that lack of control over the jury may lead to a verdict founded, if not mainly, very strongly on their disapproval of the defendant's tactics." ${ }^{129}$ John Jackson illustrates this concern with reference to a study carried out in England and Wales finding that general inferences were usually drawn to "copper fasten" an already strong prosecution case. In cases where the evidence against the defendant was weak, inferences were not drawn and it was considered inappropriate to do so. ${ }^{130}$ Furthermore, in the cases where inferences were drawn it could not be concluded that, but for the inference, the defendant would not have been found guilty anyway. ${ }^{131}$ These findings suggest that the only effective use of the general inference is to strengthen a weak prosecution case. In England and Wales such use was considered inappropriate and avoided.

The potential for injustice here can be illustrated by referring back to the logical inference provided in Priday. If the man walking into the court room was holding an umbrella alone, the

125 Although other categorisations of the evidentiary value to be given to silence have been suggested. See, for example, the categories provided by $\mathrm{C}$ Theophilopoulos "Evidentiary Value of Adverse Inferences from the Accused's Right to Silence" [2002] 15 SACJ 321 at 323.

126 Heydon, above n 53, at 54 .

127 Ibid.

128 Murray $v$ United Kingdom, above n 85. See also Averill v United Kingdom, above n 84; and the Trompert principle set out above in Part IV, B.

129 Birch, above n 97, at 774 .

130 John Jackson "Silence and Proof: Extending the Boundaries of Criminal Proceedings in the UK" [2001] 5 E\&P 145 at 155

131 Ibid. 
general inference would allow not only the conclusion that it had been raining outside, but perhaps also snowing, or even that the man had arrived at the court house riding a unicorn. In short, by circumventing the prima facie case requirement, any conclusion that may not be supported by the mere possession of an umbrella is possible.

\section{The particular inference}

It follows that the particular inference should be preferred. In its 1987 Report, the Home Office advocated the use of this inference in the England and Wales reforms. ${ }^{132}$ The Home Office recommended that any failure to comply with pre-trial disclosure should entitle the judge and prosecution to comment and the fact-finder to draw inferences. Such inferences would not be capable of amounting to corroboration. ${ }^{133}$ This inference would provide that where a defendant fails to comply with his or her disclosure requirements, a different defence argued at trial would undermine the credibility of the defendant and therefore attract the conclusion that the latter defence was untrue. ${ }^{134}$

Easton critiques this reasoning, arguing that it will be difficult to distinguish between an inference that only undermines the credibility of a particular defence and one that indicates the guilt of the defendant: "[o]nce the jury is sceptical regarding the credibility of the defendant it is more likely to find him guilty". ${ }^{135}$ The solution to Easton's concern can only be met by providing a firm direction on the extent of the inference to be drawn. ${ }^{136}$ Towards this end, cl 114 should be changed to expressly limit the evidential value of the inference to one that only undermines the particular defence advanced in contravention of the issues identification process.

\section{A Balance}

The above arguments illustrate the necessary role that consideration of prosecution disclosure, the significance of non-compliance, and the defendant's understanding of the issues plays in ensuring the inference is exercised in a fair and just way, consistent with the context of nondisclosure. Furthermore, by expressly limiting the evidential value of the inference to one that only undermines the particular defence advanced in contravention of the issues identification process, the Bill would ensure that the extent of the inference is consistent with that context. If the Bill required judges to address these mandatory considerations when deciding whether to grant leave, and to limit the extent of the inference drawn if leave is granted then the inference could be applied consistently

132 Home Office, above n 40, at [110].

133 Ibid.

134 Heydon, above n 53, at 54.

135 Easton, above n 11, at 156.

136 Ibid, at 155. Indeed, Easton, also at 155, seems to suggest this when she states "it is because of the weakness of common sense thinking that a firm judicial direction is so important". 
and justifiably. As a consequence, both its fact-finding and sanctioning functions would be maintained

\section{CONCLUSION}

This paper has analysed how the inference of guilt from non-compliance with the issues identification process will be incorporated into New Zealand law by the Criminal Procedure (Reform and Modernisation) Bill.

It has outlined the inevitable place of logical inferences in the fact-finding process and the just determination of criminal trials. Logical inferences are used to assist the prosecution in proving the defendant's guilt beyond a reasonable doubt. The paper's focus on the immunities afforded by the right to silence and the exceptions to those immunities, established that the basis for inferring guilt from non-compliance with the issues identification process stems from common sense assumptions. However, in order for these assumptions to be justified and consistently applied, it is necessary to consider the context of the non-compliance.

This contextual inquiry is problematic given the dual functions of both sanctioning and factfinding required from the inference. The England and Wales experience, particularly the implementation of the CJA, suggests that these two functions are inherently opposed. However, incorporating mandatory considerations into the Bill and limiting the evidential value of the inference, provides a consistent process that takes the necessary context into account. Accordingly, by implementing the recommended changes to the Bill, the inference of guilt - as a mechanism to ensure compliance with the issues identification process - will be exercised in a consistent and just way, in accordance with both its sanctioning and fact-finding functions. 
